\title{
Role of Mycoplasma hominis in Bacterial Vaginosis
}

\author{
Monowara Begum¹,3, Md. Nurul Alam², Kazi Mosihur Rahman'1 \\ ${ }^{1}$ Department of Microbiology, Former Institute of Postgraduate Medicine and Research, Shahbag, Dhaka; ${ }^{2}$ Department of \\ Microbiology, Dhaka Medical College, Dhaka; ${ }^{3}$ Currently, Department of Microbiology, Dhaka Dental College, Mirpur-14, \\ Dhaka
}

\begin{abstract}
A total of 115 women were investigated along with 50 controls in order to find out association of Mycoplasma hominis in Bacterial Vaginosis (BV) cases. Vaginal swabs were collected from the cases enrolled from three tertiary- level Hospitals of Dhaka City during December, 1993 to December, 1994. Specimens were cultured on appropriate media and $M$. hominis was isolated from $28(24.3 \%)$ specimens collected from patients and $3(6 \%)$ from healthy controls. The difference of isolation rate was statistically significant $(p<0.05)$ between cases and the controls. In addition to M. hominis, Gardnerella vaginalis was present in $35(30.4 \%)$, Candida spp. in 26 $(22.6 \%)$, Trichomonas vaginilis in $10(8.7 \%)$ and other aerobic bacteria in $11(9.5 \%)$ cases.
\end{abstract}

Key words: Bacterial Vaginosis, Mycoplasma hominis, Gardnerella vaginalis

\section{Introduction}

Vaginitis caused by organisms other than Candida species (Trichomonas vaginalis and Neisseria gonorrhoeae) was previously termed as non-specific Vaginitis or non-specific Vaginosis (NSV). ${ }^{1,2}$ At present, it is known as Anaerobic Vaginosis (AV) or Bacterial Vaginosis (BV). However, Bacterial Vaginosis is a polymicrobial non-inflammatory condition of the Vagina characterized by homogenous malodorous discharge with fishy smell, high vaginal $\mathrm{pH}$ and presence of Clue cells. ${ }^{3}$

Gardnerlla vaginalis had been isolated as the sole etiologic agent of Bacterial Vaginosis in 1955.1 But the present concept is that along with $G$. vaginalis, anaerobic organisms including Bacteroides species, Peptostreptococcus, Mobilluncus and

\section{Correspondence:}

Dr. Monowara Begum

Assistant Professor, Department of Microbiology

Dhaka Dental College, Mirpur-14, Dhaka.
Mycoplasma hominis act synergistically to cause Vaginitis. ${ }^{2}$ In the present study, an attempt has been made to find out the association of $M$. hominis in patients of $\mathrm{BV}$ attending outpatients of different hospitals in Dhaka City, Bangladesh.

\section{Methods}

Vaginal specimens were collected from 115 sexually active, married women, aged between 15-50 years with characteristic features of Bacterial Vaginosis (BV) who attended the Obstetrics and Gynecology Outpatient departments of Dhaka Medical College Hospital, Sir Salimullah Medical College Hospital and Institute of Postgraduate Medicine and Research (IPGMR, now BSMMU) during a period of December, 1993 to December, 1994. All the patients were symptomatic having complaints of excessive and foul-smelling vaginal discharges with or without one or more of the following symptoms: pruritus, burning sensation of Vulva and Vagina, dyspareunia, and pelvic pain. 
Menstruating and pregnant women were not included in this study.

Fifty age-matched healthy, sexually-active married women without any complaints or clinical features of BV were included as controls. None of the study or control subjects received any antimicrobial treatment a month prior to the study.

Patients were diagnosed as having BV if at least three of the following four signs were present: ${ }^{3}$ (a) thin, malodorous, homogeneous vaginal discharge; (b) vaginal fluid $\mathrm{pH}>5.0$; (c) a positive amine test; and (d) presence of Clue cells in wet mount and Gram's stained smears.

Three high vaginal swabs from each of the patients and each control subjects were collected from the lateral and posterior vaginal fornices using sterile cotton-tipped swabs and a sterile un-lubricated Cusco's speculum. The physical properties of vaginal discharge like color, consistency, etc were recorded. Before collecting specimens, each patient was interviewed and relevant information was recorded systematically. One of the swab sticks was used for direct examination such as $\mathrm{pH}$ determination, wet mount preparation and Gram's staining. The second and the third swabs were used for cultures.

The culture for $M$. hominis was done as described by Hayflick and Chanock (1965) 4 and modified by FAO/WHO collaborating centre for animal Mycoplasmas. In this study, culture for Mycoplasma was done in two media: one in a complete Mycoplasma agar medium (CMAM) containing Mycoplasma agar base supplemented with Mycoplasma supplement G containing 0.025\% Thallous Acetate, 20\% Horse serum, 10\% Yeast extract and Penicillin (1000 IU/ml), and another in a Mycoplasma broth tube. The plates were incubated at $37^{\circ} \mathrm{C}$ in a micro-aerophilic condition using candle jar with high humidity for 2-7 days and the broth cultures were incubated at $37^{\circ} \mathrm{C}$ aerobically for 2-4 days.

The organisms were identified by colony morphology (typical 'fried egg' colonies), ${ }^{5}$ by Diene's stain, agar fixation technique and Giemsa stain, biochemical tests including fermentation of glucose, Arginine hydrolysis and plate spot test for Urease production. Lastly, Mycoplasma species were identified by growth inhibition test in presence of dried antiserumimpregnated paper discs. ${ }^{6}$
The third vaginal swab was inoculated on Sabouraud's dextrose agar for isolation of Yeast, on Vaginalis agar for isolation of $G$. vaginalis, on Blood agar and MacConkey's agar for the isolation of other common aerobic bacteria. All the suspected organisms were identified by their colonial morphology, Gram's staining, oxidase and catalase reactions, sugar fermentation and other biochemical tests as per standard methods.

The specimens from control subjects were collected and processed in a similar way.

The data were systematically recorded for statistical analysis. All the data were analyzed by Student's t-test and Z-test.

\section{Result}

A total of 115 women characterized as suffering from Bacterial Vaginosis (BV) were investigated. Some 31 strains of $M$. hominis were isolated of which 28 (90.32\%) from BV patients and rest $03(9.68 \%)$ from the controls. (Table I) The organisms were isolated alone or in combination with others.

Table I: Rate of isolation of various organisms from the study population and the controls

\begin{tabular}{lll}
\hline Microorganism & \multicolumn{2}{c}{ No. of isolates in- } \\
& BV patients & Controls \\
\hline M. hominis $(\mathrm{n}=31)$ & $28(90.32 \%)$ & $03(9.68 \%)$ \\
G. vaginalis $(\mathrm{n}=40)$ & $35(87.5 \%)$ & $05(12.5 \%)$ \\
Candida spp. $(\mathrm{n}=30)$ & $26(86.67 \%)$ & $04(13.33 \%)$ \\
T. vaginalis $(\mathrm{n}=12)$ & $10(83.33 \%)$ & $02(16.67 \%)$ \\
Other aerobic bacteria $(\mathrm{n}=16)$ & $11(68.75 \%)$ & $05(31.25 \%)$
\end{tabular}

Considering association of $M$. hominis, G. vaginalis and other organisms in patients of $\mathrm{BV}$, it is found that 23 out of 115 (20.0\%) of BV patients had polymicrobial etiology. The highest rate of mixed organisms, $M$. hominis and $G$. vaginalis (13, 11.3\%) were found among BV cases. (Table II) 
Table II: Polymicrobial etiology with respect to Mycoplasma in 115 patients of bacterial vaginosis

\begin{tabular}{lll}
\hline Microorganisms & $\begin{array}{l}\text { Patients } \\
(\mathrm{n}=115)\end{array}$ & $\begin{array}{l}\text { Controls } \\
(\mathrm{n}=50)\end{array}$ \\
\hline M. hominis alone & $9(7.8 \%)$ & $0(0 \%)$ \\
G. vaginalis alone & $18(15.6 \%)$ & $3(6.0 \%)$ \\
$M$. hominis + G. vaginalis & $13(11.3 \%)$ & $1(2.0 \%)$ \\
M. hominis + Candida spp. & $2(1.7 \%)$ & $0(0 \%)$ \\
M. hominis + T. vaginalis & $4(3.4 \%)$ & $2(4.0 \%)$ \\
G. vaginalis + Candida spp. & $4(3.4 \%)$ & $1(2.0 \%)$ \\
Candida spp. alone & $20(17.3 \%)$ & $3(6.0 \%)$ \\
T. vaginalis alone & $6(5.0 \%)$ & $0(0 \%)$ \\
Other aerobic bacteria alone & $11(9.5 \%)$ & $5(10.0 \%)$ \\
No organisms isolated & $28(25.0 \%)$ & $35(70.0 \%)$ \\
\hline
\end{tabular}

$\mathrm{P}<0.01$ : Compared between organisms isolated in patients and in controls in each category $\mathrm{P}<0.05$ : Compared between $M$. hominis as a single pathogen from patients and controls

\section{Discussion}

Though M. hominis emerged as an etiological agent of Bacterial Vaginosis (BV), no study has been reported on the role of $M$. hominis in Bangladesh. It seems that many infection of lower genital tract caused by $M$. hominis remained unidentified because of fastidious nature of the organism and its unfamiliarity as a human pathogen. In the present study, M. hominis was isolated from $24.3 \%$ (28 out of 115) cases of BV either alone or in combination with other organisms which is similar to those of the other investigators. ${ }^{7}$ In USA, Paavonen et al isolated $63 \% \mathrm{M}$. hominis from BV and 19\% from healthy women. ${ }^{2}$ Blackwell et al in 1982 in UK isolated higher percentage of the organism from BV patients. ${ }^{8}$ The isolation rate in developed countries is higher probably due to their high prevalence of sexually transmitted disease (STD). Moreover, the criteria of having $\mathrm{BV}$, procedure of cultivation and identification in different laboratories vary.

Polymicrobial etiology in BV reported in this study (20\%) is in accordance with those of many workers. M. hominis and G. vaginalis are significantly $(11.3 \%)$ associated with BV in present study which is lower than that $(85 \%)$ of the study of Lefevre et al. ${ }^{9}$ Because of lack of facilities, we could not look for anaerobic bacteria and Chlamydia trachomatis which might be associated with vaginosis. Specific identification of obligate anaerobes is unnecessary for confirmation of BV. ${ }^{10}$
In the present study, the complaints of the patients were offensive vaginal discharge, pelvic pain, itching, dyspareunia and dysurea. It has been associated with pelvic inflammatory disease, UTI, cervical intraepithelial neoplasia, menorrhagia and post-hysterectomy vault infection in a few studies. The $\mathrm{BV}$ has been implicated in recurrent miscarriage, premature rupture of membrane, preterm labor. ${ }^{11,12}$ Hence, those women who are at higher risk of preterm birth, with a history of recurrent miscarriage or symptomatic must be screened and treated with Metronidazole or Clindamycin.

From this study, it is evident that from about one fourth cases of vaginosis, $M$. hominis could be isolated and thus reinforce involvement of the organism in vaginosis. So, knowing the etiological agent in time helps in treating the patients effectively and rationally.

\section{References}

1. Gardner HL, Dukes CD. Haemophilus vaginalis Vaginitis: A newly defined specific infection previously classified as 'nonspecific' Vaginitis. Am J Obstet Gynecol 1955; 69: 962.

2. Paavonen J, Miettinen A, Stevens CE, Chen KC, Holmes KK. Mycoplasma hominins in non-specific Vaginitis. Sex Transm Dis 1983; 10: 271-275.

3. Amsel R, Totten PA, Spegel CA, Chen KCS, Eschenebach D, Holmes KK. Nonspecific Vagintitis: Diagnostic criteria and microbial and epidemiological association. Am J Med 1983; 74: 14- 22.

4. Hayflick L, Chanock RM. Mycoplasma species of man. Bacteriol Rev 1965; 29: 185-221.

5. Razin, Freundt EA. The Mollicutes Mycoplasmatales and Mycoplasmataecae. In: Bergey's Manual of Systemic Bacteriology, Vol I. Baltimor, US: Williams and Wilkins; 1984: pp. 740-760.

6. Stanbridge E, Hayflick L. Growth inhibition test for identification of Mycoplasma species utilizing dried antiserum impregnated paper discs. J Bacteriol 1967; 93: 1392-1396.

7. Bhatt M, Deodhar LP, Gogate A, Vaidya RP, Patel MV. Mycloplasmas in female genital tract. J Postgrad Med 1985; 31 : 112-114.

8. BlackWell A, Barlow D. Clinical diagnosis of anaerobic vaginosis (non-specific Vaginitis), a practical guide. $\mathrm{Br} \mathrm{J}$ Venereal Dis 1982; 58: 387-393.

9. Lefevre JC, Averous S, Bavriaud R, et al. Lower genital tract infections in women. Sex Transm Dis 1988; 15: 110-113. 
10. Levett PN. Bacterial Vaginosis. W Ind Med J 1989; 38: 126-132.

11. Tuly JG, Smith LG. Post-partum septicemia with Mycoplasma hominis. JAMA 1968; 204: 827-8282
12. Waites KB, Rudd PT, Crouse DT, et al. Chronic Ureaplasma urealyticum and Mycoplasma hominis infections of the central nervous system in preterm infants. Lancet 1988; i: 17-21. 